Jurnal Pendidikan Matematika : Judika Education

Volume 1, Nomor 1, Januari-Juni 2018

e-ISSN : 2614-6088

p-ISSN : 2620-732X

DOI: https://doi.org/10.31539/judika.v1i1.243

\title{
PENGEMBANGAN POCKET BOOK BERBASIS PENDEKATAN MATEMATIKA REALISTIK INDONESIA (PMRI) MATERI BANGUN RUANG SISI DATAR
}

\author{
Drajat Friansah $^{1}$, Idul Adha ${ }^{2}$, Rani Refianti ${ }^{3}$ \\ STKIP-PGRI Lubuklinggau ${ }^{1,2,3}$ \\ drajatfriansah@yahoo.com ${ }^{1}$
}

\begin{abstract}
ABSTRAK
Tujuan dari penelitian ini adalah untuk menghasilkan pocket book materi bangun ruang sisi datar yang valid dan praktis berdasarkan pendekatan matematika realistik Indonesia (PMRI) dan mengetahui efek potensial yang muncul dari pengembangan pocket book serta respon siswa terhadap pocket book yang dikembangkan. Penelitian ini merupakan penelitian kuantitatif dengan desain Research and Development $(R \& D)$. Pengembangan pocket book ini dilakukan melalui dua tahapan yaitu tahap priliminary (persiapan) dan tahap formative evaluation. Hasil penelitian ini menunjukan bahwa pocket book bangun ruang sisi datar menggunakan pendekatan PMRI yang dihasilkan valid dan praktis. Valid tergambar dari hasil revisi setelah divalidasi oleh pakar berdasarkan konten, konstruk, dan bahasa. Berdasarkan analisis dokumen hasil pengerjaan siswa saat field test, menunjukan tes akhir pembelajaran menggunakan pocket book dengan pendekatan PMRI mendapatkan kategori sangat baik 43,75\%, baik 28,12\%, Cukup $15,62 \%$, dan kurang $12,5 \%$, data hasil tes tersebut bahwa pembelajaran yang dilakukan menunjukkan efek potensial yang baik. Berdasarkan analisis hasil respon siswa terhadap pocket book yang dikembangkan untuk indikator ketertarikan pada pocket book diperoleh $86,09 \%$ siswa menyatakan sangat setuju, indikator materi 79,97\% siswa setuju dan indikator dari segi bahasa 89,32\% siswa sangat setuju. Simpulan, pocket book yang dikembangkan berdasarkan pendekatan matematika realistik Indonesia (PMRI) dinyatakan valid dan praktis untuk digunakan serta memiliki efek potensial yang baik dan menarik bagi siswa.
\end{abstract}

Kata Kunci : Pengembangan Pocket Book, PMRI

ABSTRACT
The purpose of this study is to produce a pocket book of valid and practical flat
side space material based on the Indonesian realistic mathematics approach
(PMRI) and determine the potential effects arising from the development of pocket
books and student responses to the developed pocket books. This research is a
quantitative study with the design of Research and Development (R\&D). The
development of this pocket book is carried out through two stages, namely the
priliminary (preparation) stage and the formative evaluation stage. The results of
this study indicate that the pocket book builds flat side space using the PMRI
approach that is produced valid and practical. Valid drawn from the results of
revision after being validated by experts based on content, construct, and
language. Based on the document analysis of the results of student work during
the field test, showed the final test of learning using a pocket book with PMRI 
approach got a very good category $43.75 \%$, good $28.12 \%$, Quite $15.62 \%$, and less $12.5 \%$, the result data the test is that the learning performed shows good potential effects. Based on the analysis of the results of student responses to the pocket book developed for the indicator of interest in the pocket book obtained 86.09\% of students expressed strongly agree, material indicators $79.97 \%$ of students agreed and indicators of language $89.32 \%$ of students strongly agreed. In conclusion, pocket books developed based on the Indonesian realistic mathematics approach (PMRI) are declared valid and practical to use and have good and interesting potential effects for students.

Keywords: Pocket Book Development, PMRI

\section{PENDAHULUAN}

Bangun ruang sisi datar merupakan salah satu pokok bahasan yang termasuk dalam kategori geometri ruang atau dimensi tiga. Ada banyak benda dalam kehidupan sehari-hari yang berbentuk bangun ruang geometri seperti kotak mainan berbentuk kubus atau balok, piramida dengan bentuk limas, dan lain sebagainya. Jika ditinjau dari segi kurikulum pengajaran dapat dilihat bahwa geometri diajarkan dari jenjang Sekola Dasar (SD) hingga sekolah Menengah atas (SMA).

Pada kenyataannya ada banyak kesulitan yang dihadapi siswa dalam memahami materi bangun ruang sisi datar baik pada pokok bahasan luas permukaan ataupun volume. Suwaji (2008) Menyatakan siswa menghadapi kesukaran dalam membayangkan suatu balok yang berongga di dalamnya. Hal ini menyebabkan siswa kesulitan dalam memahami konsep volume bangun datar. Selanjutnya Suwaji (2008) menyatakan berdasarkan hasil Ttraining Need Asesment (TNA) calon peserta diklat guru matematika SMP yang dilaksanakan PPPPTK tahun 2007 dengan sampel 268 guru SMP dari 15 propinsi menunjukan bahwa untuk materi luas permukaan dan volume balok, kubus, prisma serta limas, menunjukan 43,7 \% guru sangat memerlukan materi luas permukaan . Sehubungan dengan hal tersebut dibutuhkan sebuah alternatif yang dapat membantu siswa dalam memahami luas permukaan dan volume bangun ruang sisi datar.

PMRI merupakan salah satu alternatif pembelajaran yang menghubungkan antara matematika dengan kehidupan sehari-hari. Sembiring (2010) menyatakan bahwa PMRI amat penting dalam mengembangkan contoh materi ajar dan juga bahan ajar. Adapun materi ajar atau bahan ajar yang biasa dikembangkan biasanya dikemas dalam ukuran yang cukup besar berupa LKS (Lembar Aktivitas Siswa) atau buku ajar. Guna menghasilkan bahan ajar yang praktis maka pocket book atau buku saku merupakan salah 
satu alternatif dalam pembelajaran matematika.

Pembelajaran matematika termaksuk luas permukaan volume bangun ruang sisi datar sangat berkaitan dengan kehidupan seharihari, ada banyak hal dalam kehidupan yang melibatkan bangun ruang sisi datar, seperti atap sebuah rumah, kotak musik, tempat penampungan air dan lain sebagainya. Jika ditinjau dari banyaknya bendabenda dalam kehidupan yang melibatkan bangun ruang sisi datar maka dibutuhkan suatu pendekatan yang dapat memfasilitasi agar materi ini dapat lebih mudah dipahami oleh peserta didik.

\section{Pendekatan}

Matematika

\section{Realistik Indonesia (PMRI),} merupakan salah satu pendekatan dalam pembelajaran matematika yang dapat membantu siswa dalam memahami konsep bangun ruang sisi datar, dimana pembelajaran dapat dimulai dengan memberikan permasalaan-permasalahan dalam kehidupan sehari-hari yang melibatkan bangun ruang sisi datar. Hal ini yang mendasari dikembangkannya pocket book menggunakan PMRI.

Adapun karakteristik pocket book yang dikembangkan tidak hanya berisi rumus dan contoh soal tetapi berisikan informasi-informasi yang di rancang dan menggiring siswa untuk memahami konsep yang disajikan dimulai hal yang paling real menuju hal yang lebih abstrak. Hal inilah yang melatar belakangi dipilihnya PMRI sebagai pendekatan yang akan dipakai dalam pengembangan pocket book.

Hasil wawancara dengan guru matematika SMP muhammadiyah Lubuklinggau diperoleh data bahwa kesadaran matematika siswa masih tergolong rendah, matematika dianggap sebagai bagian dari mata pelajaran yang menakutkan bagi siswa, selanjutnya guru dalam menyampaikan matematika itu sendiri lebih didominasi rumus kemudian dilanjutkan dengan pemberian contoh soal.

Siswa hanya memperoleh informasi dari apa yang telah disampaikan guru. Selanjutnya juga di lakukan wawancara dengan beberapa orang siswa, ternyata diketahu bahwa siswa dalam mempelajari matematika sama sekali tidak memiliki buku paket yang dapat dijadikan pedoman. Siswa hanya mencatat informasi yang disampaikan guru dipapan tulis saja.

Berdasarkan permasalahan tersebut maka artikel berikut membahas pengembangan Pocket Book berbasis Pendekatan Matematika Realistik Indonesia (PMRI) pada materi bangun ruang sisi datar di kelas VIII, adapun Tujuan dari penelitian ini adalah untuk menghasilkan pocket book materi bangun ruang sisi datar yang valid dan praktis berdasarkan pendekatan matematika realistik Indonesia (PMRI) dan mengetahui efek potensial yang muncul dari pengembangan pocket book serta respon siswa terhadap pocket book yang dikembangkan. 


\section{METODE PENELITIAN}

Penelitian ini merupakan penelitian kuantitatif dengan desain Research and Development $(R \& D)$. Penelitian ini akan dilakukan dalam dua tahap, yaitu tahap preliminary (persiapan) dan tahap formatif evaluation. Subjek penelitian adalah siswa kelas VIII SMP Muhammadiyah Lubuklinggau.

Penelitian pengembangan ini bertujuan untuk menghasilkan pocket book dengan pendekatan PMRI yang valid, praktis, dan memiliki efek potensial. Kevalidan dari pocket book ini terlihat dari hasil validasi pakar yang didapat dari semua saran, komentar, dan masukan, serta saran dan komentar pada one-to- one.

Adapun kepraktisan pocket book dilihat dari hasil pengamatan pada uji coba small group, yang diberikan kepada kelompok kecil siswa yang terdiri dari enam orang siswa. Kepraktisan berarti mudah dipakai oleh pengguna, dibawa dan tergambar dari hasil uji coba lapangan dimana rata-rata siswa dapat menggunakan pocket book dengan baik. Efek potensial dapat diketahui dari kegiatan pada hasil field test..

Tahap awal dari penelitian ini adalah tahap persiapan (Preliminary). Tahap ini meliputi dua hal yakni tahap analisis dan pendesainan materi. Analisis dilakukan terhadap kurikulum yang dipakai di sekolah, analisis materi, analisis siswa, wawancara dan diskusi dengan guru di sekolah serta penyiapan keperluan lainnya seperti mengatur jadwal penelitian, sedangkan pendesainan materi difokuskan pada tiga karakteristik yaitu konten, konstruk, dan bahasa. Pendesainan materi bangun ruang sisi datar ini akan menghasilkan prototipe Selanjutnya prototipe yang dihasilkan akan di validasi pada tahap formatif evaluation.

Tahap formative evaluation meliputi self evaluation, expert reviews, one-to-one, small group, dan field test (Tessmer, 1993; Zulkardi, 2002). Proses dari tahapan formative evaluation dapat dilihat pada gambar di bawah ini :

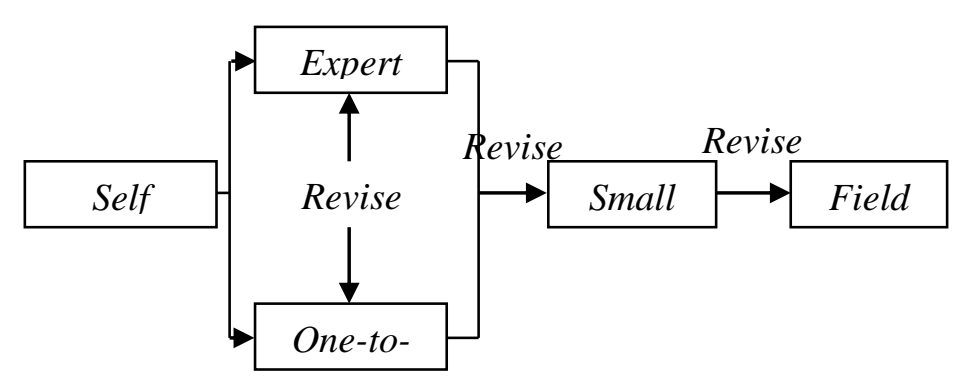

Gambar 1. Alur Formative Evaluation

Berdasarkan alur formative evaluation di atas, pada tahap Self Evaluation dilakukan peninjauan kembali terhadap prototipe materi serta kesesuaian dengan pendekatan matematika realistik indonesia yang digunakan untuk selanjutnya direvisi dan hasil dari revisi merupakan prototipe pertama. Tahap selanjutnya dari formative evaluation adalah One to one dan Expert Review (Uji Pakar). Pada tahap one-to-one ini, juga 
dilakukan uji kepada siswa secara individu. Dimana mereka memberikan tanggapan dan komentarnya terhadap produk yang dihasilkan.

Hasil komentar mereka digunakan untuk merevisi prototipe pertama. Bersama dengan uji individu (one-to-one), juga dilakukan uji pakar (expert review). Prototipe pertama yang telah didesain diberikan pada pakar untuk dievaluasi dari segi konten, konstruk, dan bahasa. Proses validasi dilakukan menggunakan Walk Trough (proses rekam dan catat) dan tulisan pakar diambil sebagai bukti validasi.

Rekaman semua proses validasi dan coretan-coretan pada dokumen/prototipe yang dilengkapi oleh komentar pakar dijadikan bukti untuk melakukan revisi terhadap prototipe pertama.

Hasil dari tahapan expert review dan one to one (prototipe kedua) selanjutnya diujicobakan pada kelompok kecil (small group) yang terdiri dari 6 orang siswa non subjek penelitian, dimana ke 6 siswa tersebut memiliki karakteristik yang sama dengan siswa yang akan menjadi subjek penelitian. Hasil uji coba small group kemudian dianalisis untuk kemudian direvisi dan menghasilkan prototipe ke ketiga dimana prototipe ketiga ini akan diujicobakan pada tahapan field test.

Adapun teknik pengumpulan data yang akan digunakan dalam penelitian ini yakni berupa dokumentasi, Walk through, tes dan angket. Dokumentasi diperoleh dari tahap one-to-one, small group. dan field test. Dapat berupa foto, video, komentar siswa dan hasil pengerjaan pocket book pada one to one, small group, dan field test. Dokumentasi yang diperoleh dianalisis untuk memperoleh data yang dijadikan dasar pada perbaikan prototipe.

Pada tahap expert review didapatkan walk through dilakukan oleh pakar. Pakar memberikan masukan/komentar atau saran terkait dengan konten, konstruk dan bahasa. Dari hasil walk through digunakan untuk revisi prototipe pertama yang akan digabungkan dengan uji one-toone untuk mendapatkan prototipe kedua

Tes digunakan untuk mengetahui efek potensial dari pengembangan pocket book kemudian hasil tes dianalisis untuk melihat efek potensial yang terjadi. Sementara itu pemberian angket dilakukan untuk mengetahui bagaimana respon siswa terhadap pocket book yang dikembangkan. Teknik analisis data dalam penelitian ini adalah analisis deskriptif kualitatif. Data yang dianalisis secara deskriptif kualitatif berasal dari dokumentasi, walk through, observasi, angket dan tes tertulis.

Tes dilakukan untuk melihat kemampuan siswa dalam menyelesaikan soal-soal yang bertujuan untuk melihat sejauh mana pemahaman siswa pada materi bangun ruang sisi datar. Analisis data tes ini 
menggunakan analisis data deskriptif dengan mencari rata-ratanya. Hasil dari rata-rata nilai siswa dikonversikan ke dalam bentuk data kualitatif untuk mengetahui hasil belajar siswa yang dapat dilihat pada tabel di bawah ini :

Tabel 1.

Kategori Kemampuan Hasil Tes

\begin{tabular}{ll}
\hline \multicolumn{1}{c}{ Nilai } & \multicolumn{1}{c}{ Kategori } \\
\hline $85,01-100,00$ & Sangat Baik \\
$75,01-85,00$ & Baik \\
$60,01-75,00$ & Cukup \\
$40,00-60,00$ & Kurang \\
$00,00-40,00$ & Sangat Kurang \\
\hline
\end{tabular}

Modifikasi Arikunto, 2010

Pemberian angket dilakukan untuk mengetahui sejauh mana respon siswa terhadap pocket book yang dikembangkan. Djaali \& Mulyono (Dalam Fadli, 2014) Jawaban setiap item instrumen yang menggunakan skala likert mempunyai gradasi dari sangat positif sampai sangat negatif yang dapat dikategorikan sangat setuju (ST), setuju (S), tidak setuju (TS), sangat tidak setuju (STS). Adapun pedoman penilaian untuk menentukan tinggi rendahnya persentase data angket yaitu menggunakan tabel di bawah ini:

Tabel 2

Kategori Tingkat Angket Respon Siswa

\begin{tabular}{ll}
\hline \multicolumn{1}{c}{ Persentase } \\
\hline $86-100 \%$ & Sangat Setuju \\
\hline $76-85 \%$ & Setuju \\
\hline $60-75 \%$ & Tidak Setuju \\
\hline$\leq 59 \%$ & Sangat Tidak Setuju \\
\hline
\end{tabular}

(modifikasi dari Arikunto, 2010)

\section{PEMBAHASAN}

Uji coba one-to-one melibatkan 3 siswa kelas VIII.3. Uji coba ini dilakukan untuk melihat validitas pocket book yang telah dikembangkan sekaligus melihat kesulitan-Tesuditakukan untuk melih siswa pada saat menggunakan pocket book dan mencatat komentarkomentar siswa pada saat uji one-toone guna sebagai bahan masukan pada tahapan berikutnya. Berikut salah satu gambar pada saat proses one to one

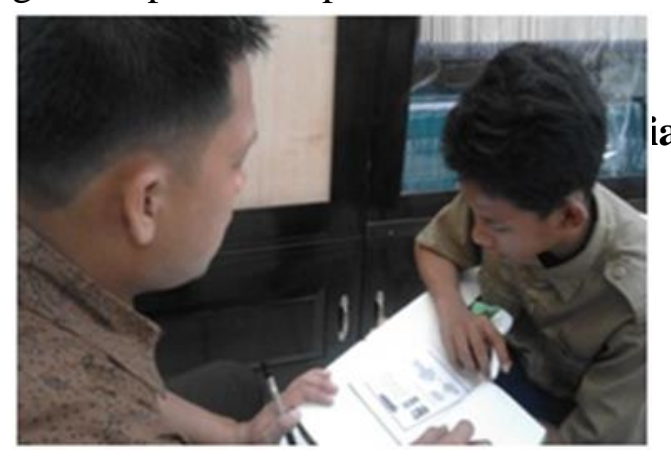

lan angket dilaku

\section{Gambar 2. Proses one to one}

Pada saat uji one to one berlangsung dilakukan pengamatan pada aktivitas-aktivitas yang dilakukan siswa dan sesekali mewawancarainya guna memperoleh informasi. Dari proses tersebut diketahui bahwasannya siswa memperoleh kesulitan memahami pocket book yang dikembangkan peneliti. Ada beberapa hal yang menjadi komentar siswa pada saat proses one to one yakni sebagai berikut :

\section{Siswa 1 :}

1. Definisi kubusnya tidak jelas antara gambar dengan definisi. 
2. Istilah luas kubus tidak jelas

3. Pada materi volume kubus istilah satuan kubus itu membingungkan

4. Tampilan dalam buku kecil kurang menarik

5. Soalnya jelas.

\section{Siswa 2 :}

1. Sampul bagian depan kurang menarik

2. Ada salah pengetikan dalam mencari luas alas kubus

3. Bingung bagaimana cara mencari $6 r^{2}$

4. Gambar kartunnya menarik

5. Rumus volume baloknya mudah dimengeri

6. Rumus luas permukaan kubus, balok, limas dan prisma mudah dimengerti. Tetapi Volume limas membingungkan

\section{Siswa 3 :}

1. Pada gambar balok tidak dijelaskan yang mana sisi yang disebut panjang, lebar dan tinggi

2. Maksud alas segi-n pada limas itu apa, sulit dipahami

3. Istilah luas prisma membingungkan

4. Tampilan buku kurang menarik

5. Sebagian isi buku kecil mudah dipahami.

6. Adapun yang menjadi komentar ahli adalah sebagai berikut :

Ahli 1 :

1. Pocket book berisikan informasi yang jelas yang dibutuhkan siswa.
2. Jika mau memasukkan unsur PMRI maka sebaiknya jangan dalam bentuk Pocket book .

3. Sebaiknya setiap pokok basan dibuat soal sebagai evaluasi siswa

4. Tampilan dalam Pocket book sebaiknya lebih berwarna.

5. Isi dari Pocket book sudah baik

\section{Ahli 2}

1. Perbaiki kalimat luas kubus, luas balok, luas limas dan luas prisma, menjadi luas permukaan kubus, luas permukaan balok, luas permukaan limas dan luas permukaan prisma.

2. Perbaiki kesalahan perhitungan pada luas alas kubus

3. Tampilan Pocket book sudah cukup menarik

4. Isi dari Pocket book sudah cukup baik, tetapi perlu dilakukan beberapa perbaikan

5. ada gambar balok sebaiknya tidak menggunakan kotak dari suatu merek dagang.

\section{Ahli : 3}

1. Terdapat banyak kekeliruan dalam penulisan huruf bersar dan huruf kecil

2. Di akhir kalimat diberi tanda titik

3. Kalimat perintah harus jelas

4. Periksa kembali setiap kalimat yang telah dituliskan.

Pada saat tahapan one to one berlangsung dilakukan pengamatan terhadap aktivitas-aktivitas yang dilakukan siswa dan sesekali 
mewawancarainya guna memperoleh informasi. Hasil dari revisi one to one dan expert review merupakan prototive 2 yang valid dan diujicobakan pada kelompok kecil (small group). Hasil revisi prototive 2 mengasilkan prototive 3 yang valid dan praktis. yang akan diujikan kepada subjek penelitian pada saat field test. Berikut dokumentasi pada saat small group.

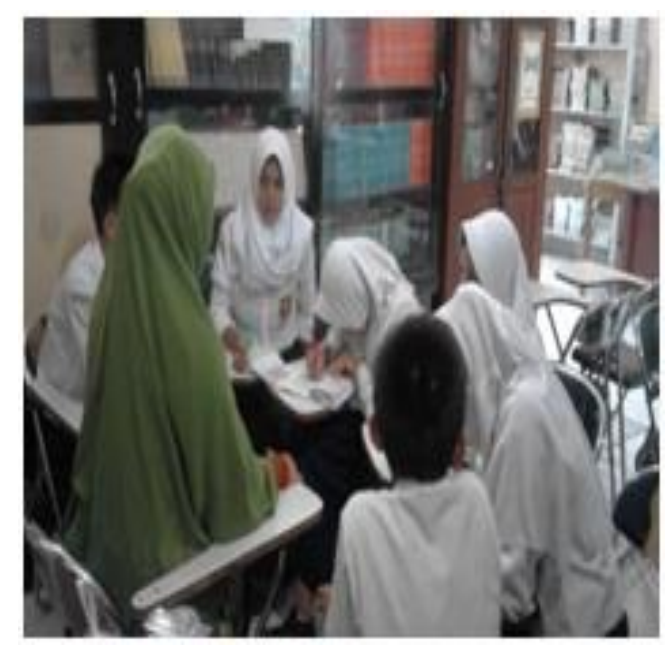

Gambar 3. Small Group

Field test dilaksanakan sebanyak dua kali yakni pada 27 April 2017 dan 13 Mei 2017 di kelas VIII.2 SMP muhammadiyah lubuklinggau dengan jumlah siswa 31 orang, yang dibagi menjadi 8 kelompok. Pada saat field test, setiap kelompok diberikan pocket book yang akan dikerjakan siswa secara berkelompok. Berikut dokumentasi pada saat field test.

Setelah melalui proses pengembangan yang dimulai dari self evaluation, one to one dan expert review, dan small group diperoleh poket book yang dikembangkan menggunakan pendekatan matematika realistik indonesia (PMRI) dikategorikan valid dan praktis. Valid tergambar dari hasil penilaian validator, dimana semua validator menyatakan baik

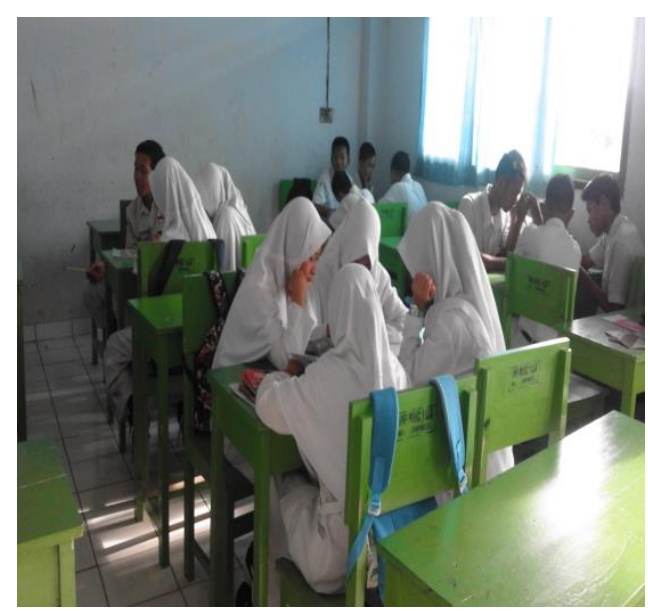

Gambar 4. Proses Field Test

Berdasarkan konten (sesuai dengan kompetensi dasar, dan indikator materi luas permukaan bangun ruang sisi datar), konstruk (sesuai dengan karakteristik/ prinsif pendekatan PMRI), dan bahasa (sesuai dengan EYD, kalimat tidak mengandung penafsiran ganda, batasan pertanyaan jelas). Praktis tergambar dari hasil uji coba lapangan dimana rata-rata siswa dapat menggunakan bahan pocket book dengan baik.

Kepraktisan pocket book dilihat dari proses pembelajaran pada saat small group, dimana semua siswa dalam kelompok tersebut dapat mengisi pocket book yang diberikan. pocket book yang telah dibuat dimulai menggunakan pendekatan PMRI yang dibantu dengan pertanyaanpertanyaan, gambar-gambar yang 
berhubungan dengan kehidupan sehari-hari, pertanyaan yang kontekstual, sehingga siswa dapat menemukan pengetahuan yang harapkan pada tujuan pembelajaran.

Salah satu tujuan field test adalah untuk mengetahui efek potensial pocket book yang dikembangkan. Efek potensial dapat dilihat dari aktivitas siswa dalam mengerjakan soal pada pocket book, dimana siswa akan lebih mudah memahami konsep matematika yang terdapat pada pocket book serta menggunakan konsep tersebut secara tepat dalam menyelesaikan persoalan yang diberikan. Adapun tabel frekuensi nilai akhir siswa adalah.

Tabel 3.

Distribusi Frekuensi Hasil Tes

\begin{tabular}{lll}
\hline Rentang & Persentase & $\begin{array}{l}\text { Kategori Hasil } \\
\text { Belajar }\end{array}$ \\
\hline $85,01-100,00$ & $43,75 \%$ & Sangat Baik \\
\hline $75,01-85,00$ & $28,12 \%$ & Baik \\
\hline $60,01-75,00$ & $15,62 \%$ & Cukup \\
\hline $40,00-60,00$ & $12,5 \%$ & Kurang \\
\hline $00,00-40,00$ & 0 & Sangat Kurang \\
\hline Jumlah & $100 \%$ & \\
\hline
\end{tabular}

Data hasil latihan tes kemampuan siswa dianalisis untuk menentukan nilai akhir dan kemudian dikonversikan ke dalam data kualitatif untuk menentukan kategori tingkat kemampuan siswa. Setelah proses filed test dilakukan selanjutnya siswa diberikan angket respon dengan responden sebanyak 31 siswa. Adapun indikator dari angket respon adalah (1) kertertarikan dengan/ materi pada pocket book dengan 5 item pernyataan, (2) Kepahaman terhadap materi yang disajikan pada pocket book dengan 5 item peryataan, (3) kepahaman terhadap bahasa dan tulisan pada pocket book dengan 3 item pernyataan.

Data hasil angket respon siswa dianalisis untuk menentukan pencapaian bahan ajar yang baik dan kemudian dikonversikan ke dalam data kuantitatif untuk menentukan kategori tingkat kemampuan siswa. Data hasil angket dapat dilihat pada tabel di bawah ini:

Tabel 4.

Data Hasil Angket Respon siswa

\begin{tabular}{lll}
\hline $\begin{array}{l}\text { Indikator } \\
\text { yang dinilai }\end{array}$ & $\begin{array}{l}\text { Persentase } \\
\text { pada Indikator }\end{array}$ & Kategori \\
\hline $\begin{array}{l}\text { Ketertarikan } \\
\text { pada pocket } \\
\text { book }\end{array}$ & $86,09 \%$ & $\begin{array}{l}\text { Sangat } \\
\text { Setuju }\end{array}$ \\
\hline Materi & $79,97 \%$ & Setuju \\
\hline Bahasa & $89,32 \%$ & $\begin{array}{l}\text { Sangat } \\
\text { Setuju }\end{array}$ \\
\hline
\end{tabular}

Analisis dari ketiga indikator di atas memberikan kesimpulan bahwa pocket book yang dikembangkan masuk dalam kategori sangat baik. Kertertarikan siswa pada materi yang disajikan pada pocket book menunjukkan pada persentase yang sangat baik, ini berarti pocket book memiliki tampilan yang bagus dan sesuai dengan kebutuhan siswa, siswa senang ketika mengerjakan pocket book, siswa termotivasi belajar ketika diberikan pocket book. 
Kepahaman terhadap materi yang disajikan pada pocket book menunjukkan bahwa materi yang disajikan baik, siswa mengerjakan dengan baik setiap halaman dan langkah pada pocket book, namun penyajian materi ini harus didukung dengan pengetahuan pendukung agar siswa lebih mudah memahami materi pada pocket book. Kepahaman terhadap bahasa dan tulisan pada pocket book sangat baik, artinya bahasa dan tulisan yang disajikan mudah dipahami dan dimengerti.

\section{SIMPULAN}

Penelitian ini telah menghasilkan pocket book bangun ruang sisi datar menggunakan pendekatan PMRI yang valid dan praktis dengan menggunakan alur Formatif Evaluation. Valid tergambar dari hasil revisi setelah divalidasi oleh pakar berdasarkan konten, konstruk, dan bahasa. Dari sisi konten. Pocket book KD dalam KTSP, dari segi bahasa pocket book yang dikembangkan telah memenuhi kaidah bahasa Indonesia antara lain sesuai dengan EYD, kalimat mudah dimengerti, dan tidak menimbulkan penafsiran ganda.

Dari segi konstruk, Pocket book yang dikembangkan sesuai dengan karakteristik pendekatan PMRI. Pocket book yang dikembangkan mudah dibawah kemana-mana dan praktis, tidak menimbulkan penafsiran ganda, dan dapat digunakan oleh semua siswa.

Dapat disimpulkan pocket book yang dikembangkan berdasarkan pendekatan matematika realistik Indonesia (PMRI) dinyatakan valid dan praktis untuk digunakan serta memiliki efek potensial yang baik dan menarik bagi siswa.

\section{DAFTAR PUSTAKA}

Arikunto, S. (2010). Dasar-dasar Evaluasi Pendidikan (Edisi Revisi). Jakarta: Bumi Aksara.

Fadli. (2014). Pengembangan Model Pembelajaran BerbasisWeb Pada Pembelajaran Matematika di Madrasah Aliyah Negeri 3 Palembang. Disertasi Tidak di Terbitkan. Jakarta: Program Pasca Sarjana Universitas Negeri Jakarta.

Sembiring. (2010). Pendidikan Matematika Realistik Indonesia (PMRI)

Perkembangan dan Tantangannya. IndoMS. JME, 1(1), 11-16

Tesmer, M (1993). Planing And Conducting Formative Evaluations: Improving The Quality of Education And Training. London: Kogan page.

Zulkardi. (2002). Developing a Learning Environment on Realistic Mathematics Education for Indonesia Student Teachers. Doctoral Disertation. Enschede: University of Twente 
2018. Jurnal Pendidikan Matematika : Judika Education 1(1); 1-11

Suwaji. (2008). Permasalahan

Pembelajaran Geometri Ruang

SMP dan Alternatif

Pemecahannya. Yogyakarta :

Pusat Pemberdayaan dan

Pengembangan Pendidik dan

Tenaga Kependidikan

Matematika. 